Abordagem 


\section{Schenberg: Nada que é Humano lhe era Estranho.}

\section{ALBERTO LUIZ da ROCHA BARROS*}

M ário Schenberg, falecido em 10 de novembro de $1990 \mathrm{em}$ Sáo Paulo, aos 76 anos, foi o mais eminente físico teórico brasileiro. Sua liderança e influência são a resposta à indagaçáo do físico norte-americano Philip Morrinson, que procurava entender o que teria ocorrido para que a física brasileira saltasse do nada para o reconhecimento internacional. Pode-se dizer que, desde as origens da física no país, não há quem não tenha direta ou indiretamente recebido sua influência.

Iniciou sua atividade como cientista trabalhando com Enrico Fermi (Nobel de 38) na Universidade de Roma, em 38. No mesmo ano colaborou em Zurique com Wolfgang Pauli (Nobel de 45). Esses dois cientistas introduziram na física uma partícula com carga elétrica e massa evanescente, batizada como neutrino.

Indo, em 40, para Washington trabalhar com George Gamow, Schenberg introduziu o neutrino na astrofísica para explicar o colapso estelar, que dá origem ao processo explosivo nas estrelas chamadas novas e supernovas. Foi denominado processo Urca ("Urca process"), pois Gamow observava que as estrelas perdiam neutrinos tal como os jogadores perdiam dinheiro no Cassino da Urca, que ele visitou no Rio. Esse trabalho deu projeção internacional a Schenberg.

Em 41, foi para Princeton trabalhar com o astrofísico indiano $S$. Chandrasekhar (Nobel de 83). Dessa colaboração resultou um artigo no qual se estuda a evolução estelar, em particular a do sol, e onde figura o chamado limite de Schenberg-Chandrasekhar. Estrelas que ficam bilhóes de anos estáveis, quando atingem esse limite, sofrem uma alteraçáo em seu "metabolismo". No caso do Sol, esse limite será atingido daqui a cinco bilhóes de anos. Seu raio começará a crescer para em seguida decrescer, e o Sol terminará como uma anã branca.

* Alberto Luiz da Rocha Barrosé físico teórico, professor do Instituto de Física da USP e antigo assistente do professor Mário Schenberg. 


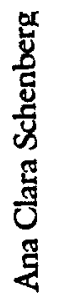


Schenberg teve intuiçóes verdadeiramente espantosas. Foi o primeiro a propor uma formulação teórica que dispensava a conservaçáo da paridade, publicada na seçáo de cartas do editor de "Physical Review" no início da década de 40. Por ser uma "carta" (letter), não repercutiu como devia. Em 56 e 57, os físicos chineses Yang e Lee, radicados nos EUA, demonstraram a violaçäo da paridade em certos processos. Por isso ganharam o Nobel.

Outra contribuição notável de Schenberg em 52 e 53 foi a que se refere à teoria geral dos métodos de segunda quantizaçáo, que permite a aplicação desses métodos à mecânica estatística clássica. Segundo o físico italiano Caldirola, com essa teoria de Schenberg há a possibilidade de se obter ainda na mecânica clássica os dois tipos de estatísticas que surgiram na mecánica quântica, a de Bose-Einstein e a de Fermidirac. Seus aspectos interpretativos e epistemológicos ainda estão por ser devidamente explorados.

Nos últimos anos, Schenberg realizou uma impressionante seqüência de trabalhos sobre as álgebras geométricas na Teoria dos Quanta, principalmente o intitulado "Mecânica Quântica e Geometria". Observava que a matéria em nível atômico ocupa o espaço de modo sutil. Com esse trabalho procurava superar a separaçăo, filosoficamente insatisfatória, entre as propriedades espaço-temporais e outras da matéria.

A preocupação com a unidade teórica da Física levou-o a propor uma teoria de unificação do eletromagnetismo com a gravitação, mas segundo um ponto de vista diferente do de seus predecessores. $O$ campo eletromagnético é que seria o campo fundamental, e não o campo gravitacional. Citando Dirac, observava que toda a medida efetuada na física é de natureza eletromagnética. O tema é objeto de uma tese de mestrado de um jovem discípulo de Schenberg, Justo Filho.

Vários físicos teóricos trabalharam e publicaram artigos com Mário Schenberg: Leite Lopes, W. Schutzer e Cesar Lattes, Abrăo de Moraes, Carmem Braga e A. L. da Rocha Barros.

Lastimavelmente, as perseguiçóes políticas e as ameaças de prisão impediram-no de exercer de modo mais direto e regular sua orientação. A teoria da supersimetria, atualmente em voga no Europa e EUA, teve suas bases lançadas aqui. Se os acontecimentos políticos fossem outros, provavelmente o capítulo da supersimetria teria os brasileiros em posiçáo de destaque.

Mário Schenberg não foi somente um cientista, foi essencialmente um intelectual, cujo espírito crítico e talentos se exerceram em muitas áreas, na crítica de arte, na história, filosofia e política. Na condiçăo de político foi membro do Comitê Central do Partido Comunista Brasilei- 
ro (PCB) desde o IV Congresso, realizado em 1967, tendo sido deputado na Assembléia Legislativa do Estado de Sáo Paulo, cassado em 1948, juntamente com toda a bancada comunista, liderada por Caio Prado Júnior. Enquanto exerceram suas atividades estes deputados fizeram incluir na Constituição do Estado de São Paulo um item extremamente criativo e dinamizador para o desenvolvimento da Ciência e Tecnologia entre nós, através de um percentual significativo para a pesquisa científica. Fato que permitiu, aliás, mais tarde, a criaçấo da Fundaçáo de Amparo à Pesquisa do Estado de São Paulo (Fapesp). Eleito pela segunda vez deputado estadual em 1962, pela legenda do PTB, em um acordo com o PCB, então na clandestinidade, sequer chegou a ser diplomado, impedido pela Justiça Eleitoral. Participou de congressos internacionais sobre o desarmamento e foi membro do Conselho Mundial da Paz. Na crítica de arte, gostava de citar quase que como uma divisa a frase de Saint-Simon: "O papel da crítica é revelar o artista a si mesmo". Por isso, só criticava quem achasse interessante.

Nos últimos anos de sua vida, quase cego, com a memória comprometida e insônia, Schenberg deu ao "Guia Corpo a Corpo", da editora Símbolo, uma de suas últimas entrevistas: "A doença grave pode destruir uma pessoa, mas também abrir um caminho. Na hora em que me sentia liquidado, o médico vinha com hipóteses de vida e o pintor Aguilar, meu amigo, me instigava, por outro lado, perguntando se a velhice não era mais uma série de renascenças que a gente sofre ao longo da existência. Praticamente esqueci tudo o que sabia, perdi as respostas que podia elaborar antes para resolver problemas... Se a gente perde uma série de informaçóes, ela (a natureza) exige que estes vazios sejam preenchidos... O estado de espírito foi mudando, meu inconsciente estava achando novos caminhos".

A ele pode-se aplicar a frase de Terêncio, que Karl Marx gostava de citar: "Sou humano, e nada que é humano me é estranho." 